\title{
Andrew Lees, a visionary mentored by a madman
}

\author{
Andrew Lees, um visionário orientado por um louco \\ Francisco Cardoso'
}

\begin{abstract}
Andrew Lees, Professor of Neurology at the National Hospital Queen Square (London, UK), has been recognized as the world's most highly-cited researcher over the 200-year history of Parkinson's Disease. Although he remains actively involved in the investigation of movement disorders, Prof. Lees embarked on a literary career that started in 2011 with the publication of a social history of his native Liverpool. His last work is Mentored by a Madman: The William Burroughs Experiment, which is reviewed here.
\end{abstract}

Keywords: Andrew Lees; William Burroughs; Gerald Stern; William Gooddy; Marcel Proust.

\section{RESUMO}

Andrew Lees, Professor Titular de Neurologia no National Hospital Queen Square (Londres, Reino Unido), é reconhecido como o mais citado pesquisador em 200 anos de história de doença de Parkinson. Embora permaneça ativamente envolvido em investigação em distúrbios do movimento, o Prof. Lees iniciou carreira literária em 2011 com a publicação de uma história social de sua native Liverpool. Seu último trabalho nesta área é Mentored by a Madman. The William Burroughs Experiment que revisado neste artigo.

Palavras-chave: Andrew Lees; William Burroughs; Gerald Stern; William Gooddy; Marcel Proust.

There are descriptions consistent with Parkinson's disease (PD) dating back many millennia. However, there is consensus that An Essay on the Shaking Palsy by James Parkinson in 1817 marks the recognition of PD as a distinct entity'. Andrew Lees (Figure 1) has been recognized as the world's most highly-cited researcher, over the history of PD. Lately, he embarked on a literary career and his last work in this area is Mentored by a Madman: The William Burroughs Experiment ${ }^{2}$. It is a memoir, with the author describing not only how he came of age as a physician and investigator, but also the history of some of his most important scientific contributions. The first-hand elegant account of landmark discoveries in the field is invaluable.

The title of Lees book is provocative and the reader becomes intrigued as to how William Burroughs (1914-1997) (Figure 2), a destructive outcast who entertained very corrosive views of physicians ${ }^{3}$, could possibly have mentored a highly-acclaimed figure of the medical establishment. Nevertheless, Lees associates many events of his formative years and career as an investigator to Burroughs. One should bear in mind that Lees attended medical school in the 1960s when the Beat Generation authors were almost mandatory reading. Paradoxically, Lees implies that, when gripped by

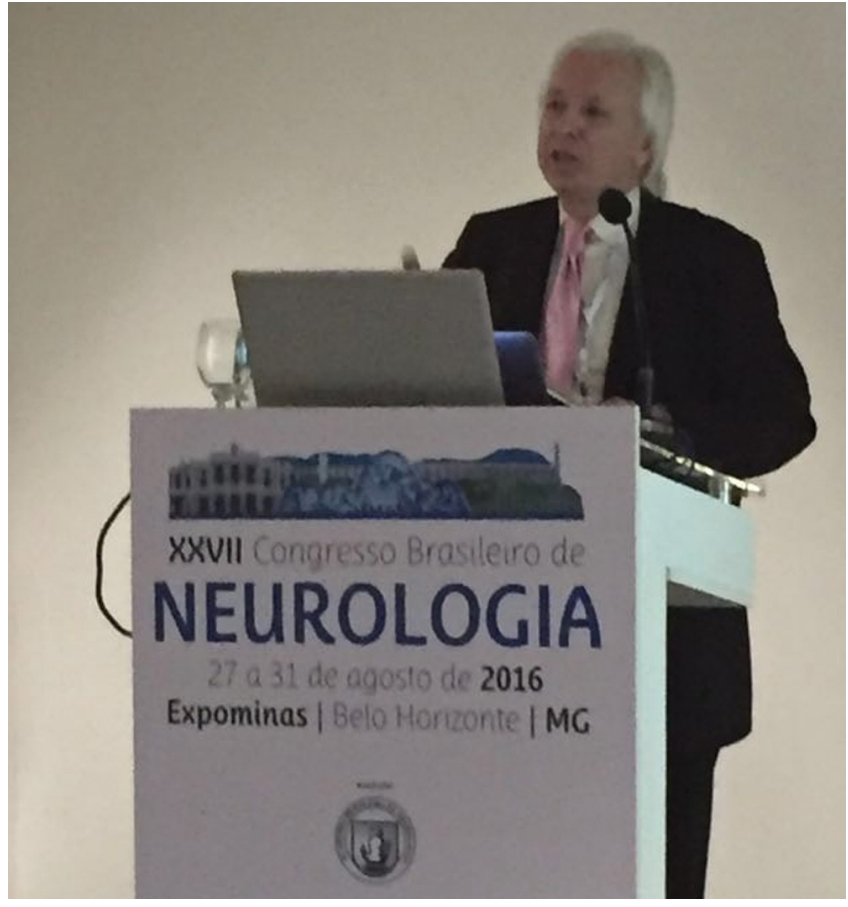

Figure 1. Andrew Lees giving a talk during the Brazilian Congress of Neurology in Belo Horizonte, August 2016. 


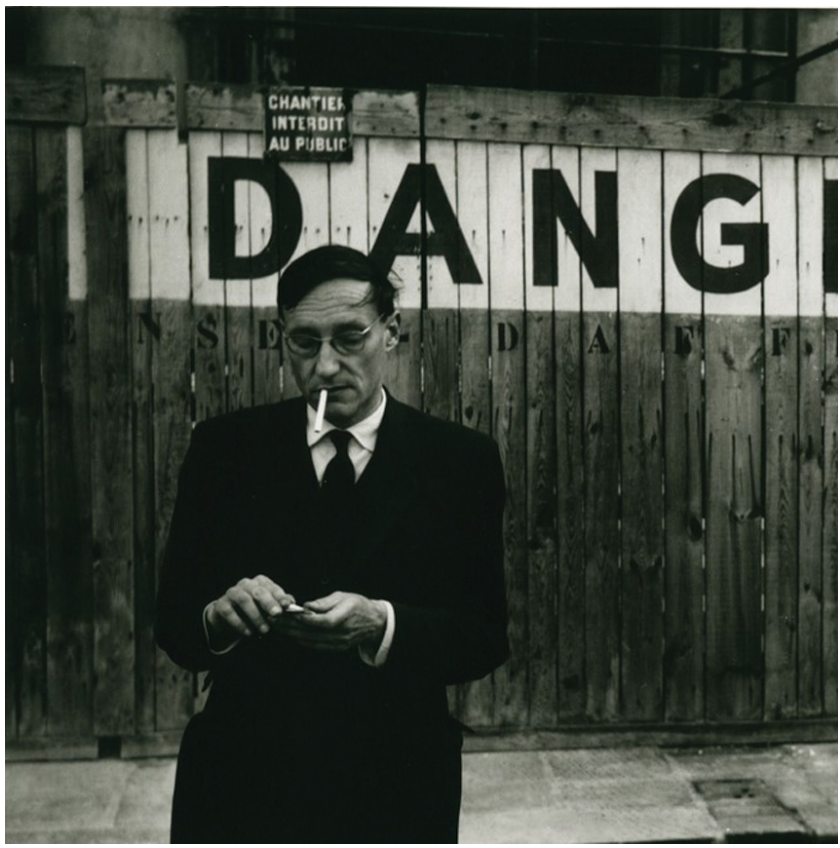

Figure 2. William Burroughs (Google images).

the temptation to quit medical school, he found solace in the depiction of doctors by Burroughs, particularly the abject Doc Benway. The introduction of apomorphine as a treatment for PD is also related to Burroughs, who himself underwent apomorphine treatment for his heroin addiction ${ }^{2,3}$. He was persuaded not to run a clinical trial of LSD in PD, after reading Burroughs' comments considering it dangerous because of the unpredictable nature of its effects. Lees' experiences of self-experimentation with anti-parkinsonian agents are also paralleled to Burroughs' extensive drug use. The most amusing of them is his intake of deprenyl, which changed his behaviour in a manner that led his wife to ask him to remain on it indefinitely (the reader is left unaware if he complied with her request). Overall, the imputed intersections between Lees' career and Burroughs' works seem less convincing of a genuine mentorship and more suggestive of coincidence or, as both would certainly prefer, synchronicity. These allusions are indicative of the unconventional nature of Lees and a reiteration of his fidelity to the spirit of the 1960s generation. This is supported by the only instance in the book where Burroughs undeniably mentored Lees: while investigating the therapeutic possibilities of yagé, Lees actually used ayahusca.

\section{THE REAL MENTORS}

The most fascinating aspect of the book ${ }^{2}$ is a glimpse of the formation of Lees. In this regard, it is necessary to mention two of his real mentors in neurology.

Professor Gerald Stern (b.1930) (Figure 3), one of his teachers during his training at The National Hospital Queen Square (NHQS), exerted a powerful influence over the young

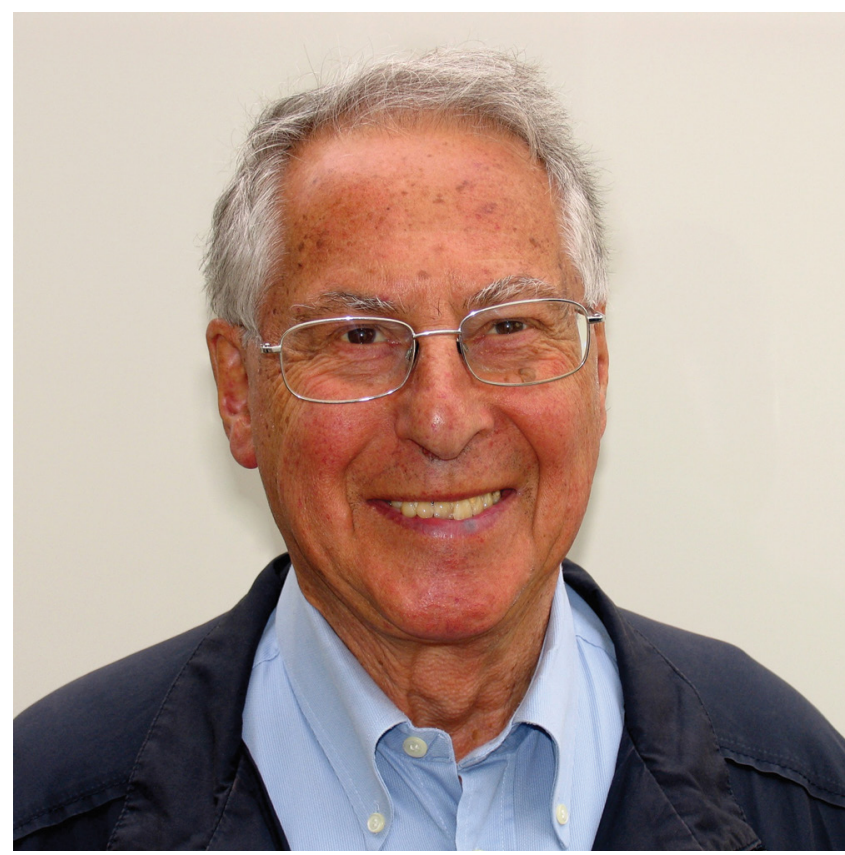

Figure 3. Gerald Stern (picture kindly sent by him to the author).

Lees. Many of his early publications have Stern as the senior author, and their partnership resulted in the introduction of apomorphine, bromocriptine and deprenyl in the management of $\mathrm{PD}^{4,5,6}$. In addition to this scientific aspect, Stern was a model of careful listening to the history of patients, as well as having a very generous attitude towards young collaborators.

Dr William Walton Gooddy (1916-2004) (Figure 4), also a consultant at the NHQS, was a man with a remarkable range of intellectual interests: neurology, literature, cosmology, pottery, music, and more. Dr. Gooddy had an idiosyncratic teaching style that can be exemplified by the answer he gave the young Lees about the recommended reading to start his neurology career: Complete Works of Sherlock Holmes by Arthur Conan Doyle and In Search of Lost Time by Marcel Proust. Not surprisingly, "in the highly competitive cauldron of Queen Square, his many interests outside medicine often counted against him"?. Unlike the rebellious Burroughs, Lees has been compliant with his teacher's recommendations: in Mentored by a Madman there are many quotations from Holmes where Lees explains how the deductive method of Sherlock is a paradigm of neurological reasoning. The interest in the famous detective was not just a young man's infatuation: in the final plenary talk of the Brazilian Congress of Neurology in 2016, Lees tackled the relationship between neurology, Sherlock, and another of his heroes, Sir William Gowers.

Aside from the recording of Gooddy's recommendation for reading In Search of Lost Time, there is no other mention of Proust in Mentored by a Madman. One possible explanation for the omission is that Lees had not read Proust. However, he confided to this reviewer that he actually read the book. The omission is only just discernible, 
as the book has many Proustian features: narration in the first person, semi-autobiographical nature, distrust of doctors (the only physician to have a sympathetic depiction by Proust is Brissaud) and, in particular, the spiral nature of the plot. In Time Regained, the narrator is found in the library of the Guermantes' mansion. While awaiting the intermission of a concert, he is able to recall his own past in full detail, being thrown into the opening scenes of his book. Lees' adventure in the Amazon Forest, described in the last chapter of Mentored by a Madman has a similar atavistic nature. It was a re-enactment of lifelong experiences and reiteration of many of his loves: the Amazon of Spruce, Burroughs, self-experimentation and the quest for a cure for PD. Here, Lees is Proust.

In the last chapter of his book, Lees had visions, visual hallucinations, induced by ayahusca. It is a very fitting end for the book that, in reality, describes not a doctor's mentoring by Burroughs, but the journey of a visionary. Lees is a man who has the vision of medicine as a compassionate blend of science and art, of doing research devoid of spurious interests and unobstructed by pointless bureaucracy, and a relentless search for a cure for PD. Mentored by a Madman is affiliated to the lineage of visionary English literature. Lees is the William Blake of neurology.

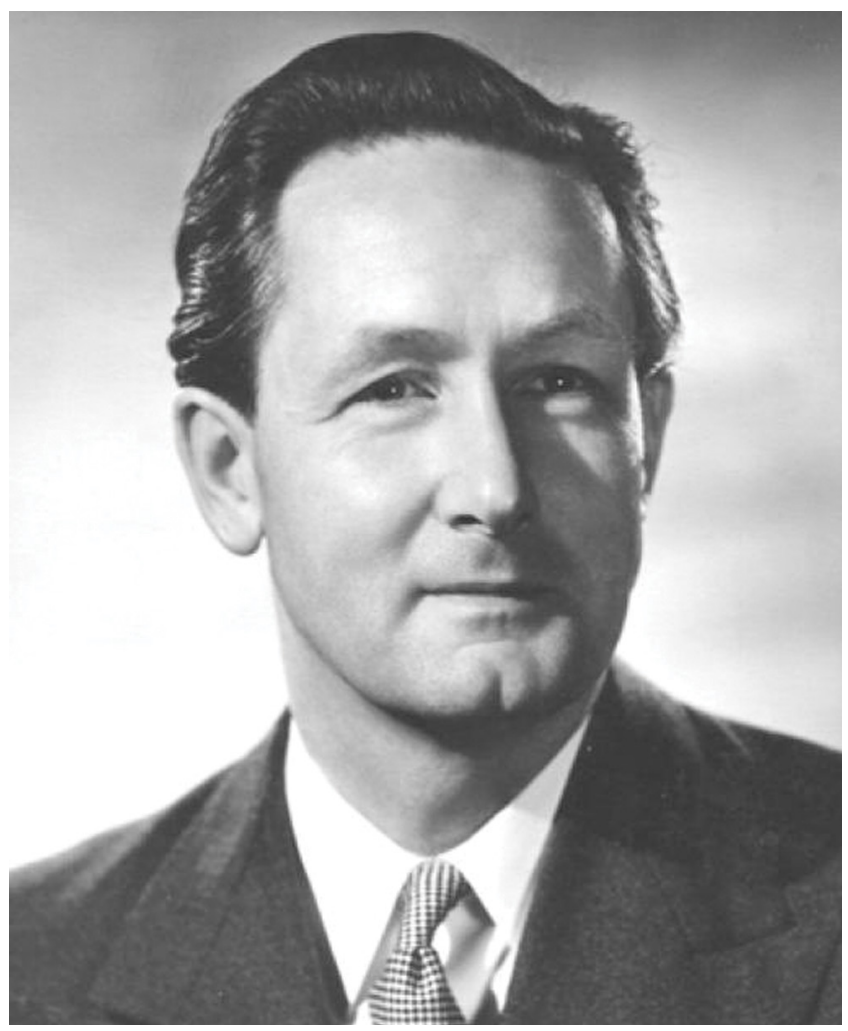

Figure 4. William Gooddy (Google images).

\section{References}

1. Parkinson J. An essay on the shaking palsy. London: Whittingham and Rowland for Sherwood, Neely and Jones; 1817.

2. Lees AJ. Mentored by a madman: the William Burroughs experiment. Devon: Notting Hill; 2016.

3. Morgan T. Literary outla: the life and times of William Burroughs. New York: W. W. Norton \& Company; 2012.

4. Lees AJ, Stern GM. Sustained bromocriptine therapy in previously untreated patients with Parkinson's disease. J Neurol Neurosurg Psychiatry. 1981;44(11):1020-3.
5. Stibe CM, Lees AJ, Kempster PA, Stern GM. Subcutaneous apomorphine in parkinsonian on-off oscillations. Lancet. 1988;331(8582):403-6. https://doi.org/10.1016/S0140-6736(88)91193-2

6. Frankel JP, Kempster PA, Stibe CM, Eatough VM, Nathanson M, Lees AJ et al. A double-blind, controlled study of high-dose L-deprenyl in the treatment of Parkinson's disease. Clin Neuropharmacol. 1989;12(5):448-51.

7. Lees A. William Walton Gooddy. BMJ 2005;330(7496):909. https://doi.org/10.1136/bmj.330.7496.909-a 